\title{
Effect in vitro and in vivo of spiramycin (embonate) on Mycoplasma hyopneumoniae
}

\author{
Marylène KOBISCH *, P. PERREAU **, F. GENIN *:* \\ * Ministère de l'Agriculture, Direction de la Qualité, Services vétérinaires, \\ Station de Pathologie porcine, B.P. 9, 22440 Ploufragan \\ *:* Institut d'Elevage et de Médecine vétérinaire des Pays tropicaux, \\ 10, rue Pierre-Curie, 94700 Maisons-Alfort \\ **** A.E.C. (Société de Chimie organique et biologique), 03600 Commentry
}

France

The effect of spiramycin on Mycoplasma hyopneumoniae was checked.

In vitro, the M.I.C. of spiramycin on two bacterial strains in a liquid medium were 0.173 and $0.347 \mu \mathrm{g} / \mathrm{ml}$ (expressed in spiramycin W.H.O. standard containing $3200 \mathrm{IU} / \mathrm{mg}$ ).

On the other hand, the therapeutic efficiency of spiramycin (embonate) was controlled in SPF piglets experimentally infected with Mycoplasma hyopneumoniae. The antibiotic was administered in a medicated feed with $250 \mathrm{ppm}$ from the age of 25 days during 10 days. The animals were contaminated at the age of 16 days. No clinical, anatomo-pathological, histo-pathological and serological signs were observed on 5 treated animals out of 7 . But, all the infected and non treated animals exhibited all these signs.

\section{Application of a health control programme in 14 "minimal disease" selection and multiplier herds}

Nathalic MAILLET *, Marylène $\mathrm{KOBISCH} * *$

* Stagiaire au C.E.M.A.G.R.E.F. de Rennes, 17, avenue de Cucillé, 35016 Remnes

**:Ministère de l'Agriculure, Services vétérinaires, Station de Pathologie porcine, B.P. 9, 22440 Ploufragan

France

A health control programme was set up and applied in 14 « Minimal disease» selection and multiplier herds in the west of France.

Serological tests were made in the sows and bacon pigs of all the herds; 3 piglets were sacrificed at the age of 8-12 weeks and subjected to bacteriological and mycoplasmic examinations.

No cascs of Aujeszky's disease and classical swine fever were detected and the situation did not seem to be alarming as for the cases of influenza, transmissible gastro: enteritis and parvovirus infection : two piglets out of 42 exhibited pulmonary lesions and the serological results were slightly positive in all the animals. Bordetella bronchiseptica was found in all the herds : the serological results indicated a contact with the germ in 100 p. 100 of the cases, but only 26 p. 100 of the autopsied piglets showed a strong or a light atrophy of the turbinates.

Haemophilus parasuis was present in 24 p. 100 of the piglets, but was not necessarily associated with lesions of the respiratory system.

Pasteurella multocida and Haemophilus pleuropneumoniae were not detected in the animals. A total of 31 p. 100 piglets did not harbour any specific pathogen. 